\title{
The Cradle (Lullabies) Songs in the Villages of Tirana
}

\author{
Ph.D. Kreshnik Duqi
}

\begin{abstract}
This study intends to represent the importance of the cradle songs (lullabies) in the Albanian folklore. The stimulus to study this topic was the importance of the expression of feelings, thoughts, values, and the bond created between a mother and her child through these songs. This is the place and the moment where is created the melody of the soul which communicates the mother's love to her child. We would like to point out some general characteristics of these songs and their resistance towards time and social changes. The language used in the verses of the lullabies used in this study is really simple, and there are not many figures of speech in them either. In these lullabies is expressed the mother's desire for her child to be healthy, by comparing the baby to the dove, the brave men and the heroes. During the expeditions in different villages of Tirana, we found out that the habitants had forgotten almost completely these lullabies and we were only able to find these songs in the areas of Krraba and Vaqarr. In this study we have analyzed these lullabies in order to better understand their background and to reach some conclusions too. In our days the lullabies are disappearing because no body sings them any more. The social and cultural development, and also the progress of technology caused these songs to be forgotten.
\end{abstract}

Keywords: lullabies, artistic communication, folklore, melodies of the soul.

\section{The cradle songs (lullabies) in the villages of Tirana.}

The cradle songs called as well as lullabies (ninna-nanna) have been used through the years as an artistic communication between the mother and the child, to put the baby to sleep. These songs occupy an important place in the Albanian folklore and have come up to our days to express the feelings, thoughts, values and the bond that is created between the mother and her child. The researcher Ferial Daja said:

Lullabies are more or less intimate monologues of the mother, but she experiences them as a real head to head conversation with her child. Referring to her child she expresses her deepest dreams and desires she has for the baby: wishing good health and a long life, high moral qualities and a good position in society. Each lullaby glows from the mother's enthusiasm and her parental love. ${ }^{1}$

The birth of a baby is the greatest joy, making a person experience feelings he/she can no longer hide, like the desire of the continuity of life. The most beautiful thing you can do with these feelings is to express them through music and songs. The lyrics of these songs express love, joy, the child's lifespan, desires and many other good wishes about the baby.

All the lullabies have in their content rhythmic expressions like "ninna-nanna", "nini-nini", "kunu kunu", "merre gjumi çunino (baby go to sleep)", etc. The wishes of a mother come out very naturally and in many cases she'll even improvise from the depth of her soul, create lines and compose melodies.

During our field research some of the bearers (grandmothers which sang lullabies to their nephews and nieces) said:

When we take our grandchildren to bed, we would start singing with "ninna-nanna" which were the main words and then would add other words improvising to our desire: "rrite gjumi çunin-o (make him grow as

${ }^{1}$ F. Daja, Folk Cradle Songs, Science Academy of the Socialist Republic of the People of Albania, The Institute of the Folk Culture, Tirana, 1982, f 4. 
he sleeps)", etc. These are not mere songs, and you don't have to sing always the exact same thing, but still, no one ever uses them. ${ }^{1}$

This means that these lullabies to them were improvisations of the moment more than genuine creations with specific lyrics that you have to memorize and than sing to the child. We must emphasize here that most of the time grandmothers were those that sang to their grandchildren, not their mothers.

Ninna-nana². Preza, Tirana, 1974. Singer: Behare Kola (woman). Bob. 1061/22

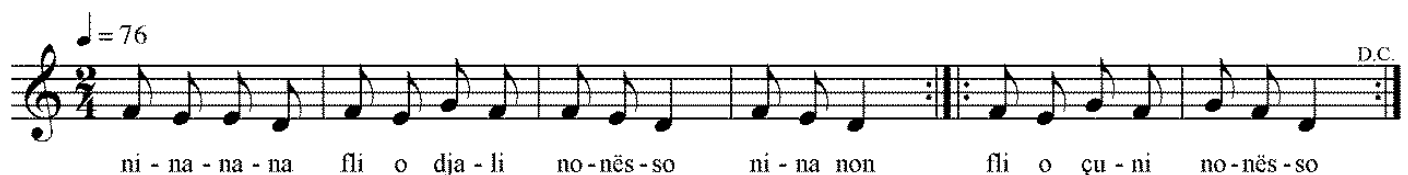

Nina-nana, fli, o djal' i nonës-o, nina-nana, fli, o çun i nonës-o të ligat t'i martë lumi; djalin nonës e zu gjumi, nina-na, nina-na.

Ninna-nanna, sleep granny's son ninna-nanna, sleep granny's boy may the river wash away the evil Granny's son fell asleep ninna-na, ninna-na. ${ }^{3}$

The musical intervals used in this song are: prima, diminished second, major second or a whole tone and the minor third. These intervals are characteristic of the folk songs in the villages of Tirana. The extent of the interval is from Re note under the staff up to the Sol note in the second line of the staff. This extent comprises a range of a pure quadruple interval and the graphic of the melody is simple.

The melody makes gradual movements of the diminished and major seconds and some leaps in the minor third, the melodic direction is descendent, ascends with overlapping and descends gradually, there is no melisma used and has a syllabic development. This song has been built on a modal scale.

It is difficult to define the mode used because it is not complete, we have four sounds and the semitone is found between the second and third sound. It could be Phrygian based on the tones, but it could be Aeolian too since this last one is used more often.

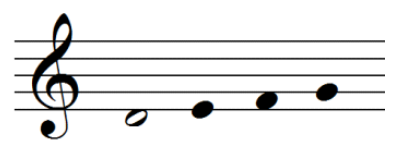

The cadence goes from up - down, overlapping in minor third but usually we are used to have gradual cadences. This song is characterized by a factor of two divisor rhythmic constructions, the material is developed with eighth-notes and quarternotes, to be more specific, the cells used have first, second and fifth measure of the song and we have pyrrhic dipody, and in the third, fourth and sixth measure we have anapest.

$$
\text { Pyrrhic Dipody }(\neg \Omega \frown \neg) \text {, Anapest }(\neg \frown \neg)^{4}
$$

Between the fourth and the fifth measure we see the sign of recurrence, which seems inappropriate and I think it's not needed here; still we can't be sure since we need to see the original cassette recording. By comparing the lyrics with the score we think that the second line must be "ninna na" not "ninna nanna" as it is in the song:

\footnotetext{
1 Individual interview with the songs' bearer.

2 H. Filja: "Folk Songs of the central Albania", The Science Academy of the Socialist Republic of the People of Albania, The Institute of the Folk Culture, "Mihal Duri" Press, Tirana 1991, f 27.

3 This song is found and written in notes by F. Daja

4 S. Shupo "The Albanian folk music", Asmus, Tirana, 2002, f 290.
} 
Nina-nana, fli, o djal' i nonës-o, nina-na, fli, o çun i nonës-o,

\author{
Ninna-nanna, sleep granny's son \\ nina-na, sleep granny's boy
}

And we find it necessary that the musical transcription should be complete, and not only for the first two lines, since the melody that follows is different. We understand that from the fact that the lines don't have the same number of syllables. The first line has eleven syllables, the second has ten syllables, the third and the forth have eight syllables each and the fifth and the sixth have six syllables each.

In this song the grandmother or the mother is expressing her love for the child. The exclamatory "o" is expressing a feeling, a mother's desire for the child to suffer no evil. The repetition adds into the song the feeling of love; we see that she uses the synonyms "son-boy". We don't see many figures of speech used here because these lyrics are a natural flow of improvisation coming from the heart. Also we see that the dialect used is traditional for the villages of Tirana: "nonës-o" (mother's-o) instead of the letter 'ë' it is used the letter ' 0 '. The original word that should be used here is nëna (which means mother but sometimes grandmother too, depending on the dialect of the area).

Ninna-nanna little boy¹. Ndroq, Tirana, 1974. Singer: Sherife Shehu (woman). Bob. 1058/8

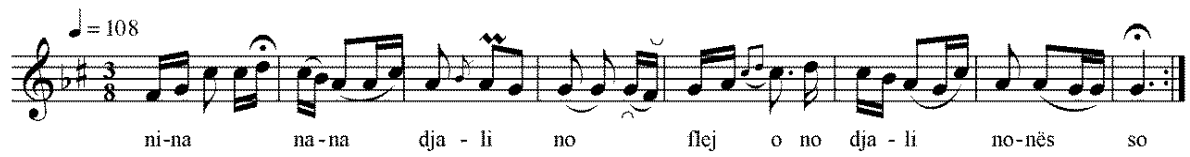

Nina-nana, djalin-o,

flej, o djal' i nonës-o,

flej, o bir i nonës, bir.

se ty gjumi të bon mirë.

të bon mir' e t'rehaton, trupin, bir-o, ta pushon.

Flej, o bir i nonës, n'djep,

t'i bohesh nonës trim me fletë; To become "a brave man with wings" (as a dragon)

trim me flet' e i bukur-o,

e t'i ngjash ti babës-0.

Baba t'la të vogël-o,

amanet t'la pushkën-o;

rritu, rritu shpejt e shpejt,

t'i morsh hakun babës vetë.
${ }^{7}$ Nina-nana, ninna nanna little boy-o

Take a sleep, granny's boy-o

Go to sleep o granny's son, my son

Because the sleep is good for you

Makes you feel good and feel comfort

It will make your body rest, son-o

Go to sleep granny's boy-o,

"a brave man with wings" and handsome too-0

Just like your father-o.

Your father left you as a baby-o

His rifle was his last will to you-0

Grow, grow fast and quickly

To revenge your father

The intervals used in this song are: perfect unison, diminished second, major second, augmented second, augmented third and the augmented fourth.

Based on intervals used in this song we see oriental influences. The extent is from note Fa in the second intervening space up to the note $R e$ on the fourth line, the interval of the sixth major. The melody is built over gradual movements and with leap points. Graphically we see an up and down pattern followed by melismas. Until now, we are used to see an augmented second but in this song we see the usage of augmented third and fourth which is extremely rare.

The Mode is extremely rare too.

\footnotetext{
${ }^{1} \mathrm{H}$. Filja: "Folk Songs of the central Albania", The Science Academy of The Socialist Republic of the People of Albania, The Institute of the Folk Culture, "Mihal Duri" Press, Tirana 1991, f 28.

2 Music collected by H. Filja, lyrics collected by M. Dule, and written in notes by H. Filja.
} 


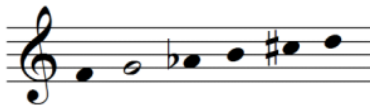

The cadence is made gradually from up to down. As the researcher Hysen Filja describes in his work "Central Albania folk songs":

\section{"These cadences are very common in the Central Albania folk songs."}

It is built on a triple time (3/8) dominated by eighth-notes and sixteenth-notes and in every measure and we can hear the syncope.

The lyrics comprise on fourteen lines and each line has seven syllables. The mother rates sleep as the most important for a child's growth. Sleep is the most important for a baby because it gives him rest, helps his body grow, refreshes his mind and prepares him to become a hard worker but also to make him brave (during the times of war). The word "brave" means handsome too. The mother wishes her son to take the best familiar traditions and carry them through generations. As our well-known writer Ismail Kadare says: "the gun is the backbone of every Albanian". The word "revenge" in this song doesn't mean blood feud but to make justice, to bring freedom, etc.

Here we find a metaphor: "A brave man with wings" which according to the mythology is the man with the wings of a dragon, and we find again the exclamatory "o".

Nini-nini nin-nin-o². Peza, Tirana, 1974. Singer: Xhene Dedja (woman). Bob. 1134/2
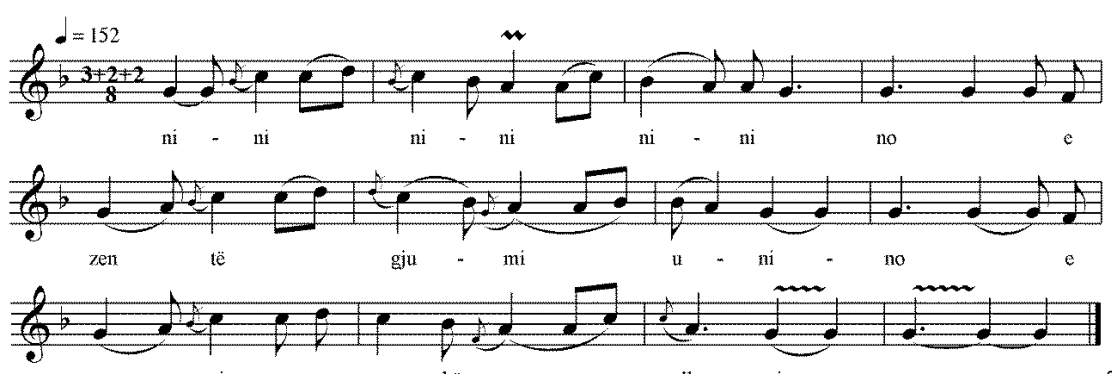

çu - n

ne

gu - shë pu

- $\mathrm{llu}-\mathrm{mi}$

no

Nini-nini, nin-nin-o,

zene, gjumi, çunin-o,

çunin gushpëllumbin-o.

Djepja me çarçaf të hollë, rritu, bir, të t'çoj në shkollë;

djepja me çarçaf si vdorë,

t'm'i boesh nanës doktor;

rritu, bir, i fort', vigan,

të punosh ti për vatan.
Nini-nini, nin-nin-o,

go to sleep little boy

my boy, as beautiful as a dove-o.

Your cradle has white sheets

Grow up my son; l'll take you to school;

Your cradle has white sheets,

I want you to be a doctor;

Grow up, my son, strong as a giant,

Grow up to work for your country.

The intervals used in this song are: minor second, major second, minor third and pure quadruple. Its extent goes from the note $\mathrm{Fa}$ in the first intervening space up to the note $R e$ in the fourth line, comprising a range of the major sixth interval. The

\footnotetext{
${ }^{1} \mathrm{H}$. Filja: "Folk Songs of the central Albania", The Science Academy of The Socialist Republic of the People of Albania, The Institute of the Folk Culture, "Mihal Duri" Press, Tirana 1991, f 6.

$2 \mathrm{H}$. Filja: "Folk Songs of the central Albania", The Science Academy of The Socialist Republic of the People of Albania, The Institute of the Folk Culture, "Mihal Duri" Press, Tirana 1991, f 29.

3 The music of this song has been found by $\mathrm{O}$. Xhatufa, the lyrics have been collected by $\mathrm{F}$. Reka, and has been written in notes by $\mathrm{H}$. Filja.
} 
melody begins with a leap in quadruple meter from down - up and later it is in a gradual motion until it leaps again in minor third meter and goes back in gradual motion, repeating this pattern several times. The leaping motions are altered with the gradual motions which are more often. The melody is melismatic. In this song acciaccatura is widely used and it gives a special character to the song.

The mode is thought to be partly Aeolian because the sixth interval is missing to define it.

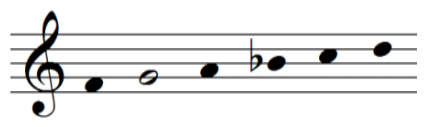

The cadence is from up to down and what makes this song so special is the vibration of the voice. The meter used is a little unusual for a lullaby (7/8) because more often are used meters $2 / 4,3 / 4,3 / 8$, etc. In most cases the meter used corresponds to the rhythm of the cradle motion.

We think this song has been written a little later than the others before, because in its lyrics we find the mother's desire for her son to go to school and become a doctor by profession. Many years ago a child would only be educated by the family because there were no schools, but here we see that the school is mentioned as an educational institution. The rhyme here, in the Albanian language, is more evident.

After comparing with the original cassette recording, we found out these missing lines of the song:

E kur të ecësh t'dundet dheu

Të jesh i fort si Skënderbeu

E biri nonës zog skefteri

Të boesh ushtar i Enverit

E biri nonës zog skefteri

E të bohesh ushtar i Enverit when you walk the earth quakes ${ }^{1}$

be as strong as Skanderbeg

little mom's boy like a falcon's bird

to be the soldier of Enver

little mom's boy, a falcon's bird

to be the soldier of Enver

If we see the lines missing, we realize that this song has been written during the last decades. It is obvious at the line: "të boesh ushtar i Enverit" (to become a soldier of Enver) and we think here the author is talking about Enver Hoxha, the former leader of our country during the socialism in Albania; And in the new transcription of this song we see the comparison of the child with Skanderbeg, our National Hero.

O nina-nina little boy². Zall-Herr, Tirana, 1974. Singer: Fiqirete Çani (woman). Bob. 1132/7

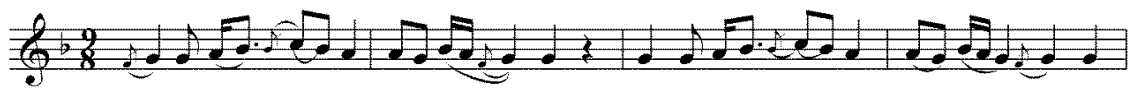

Oh nína na - na çu ni mo no 0 ni-na na m na ça * ni - no

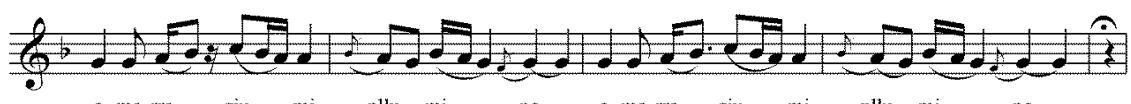

me-rre giu - mi pllu - mi

no

O ninna nanna little boy

0 , nina-nina, çunin-o,

0 , merre, gjumi, pllumin-o;

0 , përkun nat' e përkun ditë,

0 , që t'm'i japsh gëzim në jetë.

0 , që t'më rritesh çik' nga 'i çikë.

0 , të rrit nana ty azgan,

o- Come sleep take my little dove away

0 - Rock the cradle night and day

o- give him joy in life anyway

0 - Raise him up little by little ${ }^{14}$

o- Mother will raise you up my brave son

1 Transcripted from cassette 1134/2.

2 H. Filja: "Folk Songs of the central Albania", The Science Academy of The Socialist Republic of the People of Albania, The Institute of the Folk Culture, "Mihal Duri" Press, Tirana 1991, f 31. 
0 , që t'i ngjash stërgjyshve tanë;

0 , të rrit nana trim me fletë,

0 , që t'mi' japsh gëzim në jetë.
0 - be the same as your ancestors

0 - Mom will raise a brave man

o- my son gives joy to my life. ${ }^{1}$

The musical intervals used in this song are: prima, major second and minor third. If we see the acciaccatura the extent of this song would comprise a range of the fifth, starting from the note $\mathrm{Fa}$ at the first intervening space to the note Do at third intervening space. We see the graphic of the melody in two measures, at the first one it goes up and then down while in the second measure goes down and than leaps to the third minor and then goes down again. And all this song is built on these two measures.

The Mode: Aeolian or Phrygian

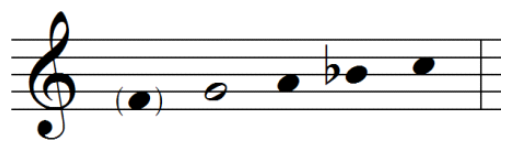

In this case the Cadence is made from up - down because the Fa note which is acciaccatura will be considered as a decoration and not as an authentic note, although it is used all the time. The meter used in this song is $9 / 8$.

In this song we notice a difference from the other songs, since the exclamatory "o" is used at the beginning of each line in the context of the melody and there is no rhythm at the end, as we have seen it in the songs above. In this song, just like in the others above, sleep is highly rated and we see this in the lines where it says: "rock it (the cradle) during the night and rock it during the day" meaning that the baby should sleep during the night and during the day too because the sleep will make him/her healthy. Each line of this song is repeated twice.

In this song we notice words of the north dialect, like 'azgan' which means 'burly' and in our case, brave. In the first and the second lines we see the use of epanalepsis-the repetition of the same word at the beginning and at the end of the same line, which in our case it is the exclamation "o", and we also see used twice a raw of the same word "çik' nga i çikë" meaning 'little by little'. Even for this song in the original material there are more lines than are used in the published materials. These lines are:

\section{O trim ushtar-o i Partisë \\ O t'mbrosh kufijt e Shqipëris \\ O nina nina çunin-o \\ O nina nina çunin-o}

\author{
O Brave soldier of our party 2 \\ $O$ to defend the borders of your country \\ O ninna ninna little boy 0 \\ O come you Sleep and take my little dove
}

Since it is a huge amount of work to check all the transcriptions, we only studied what we can see from the materials we have in hand, and by comparing the lines with each-other we noticed little mistakes as in: "Oh ninna nanna my little boy-o" which instead should be: "O ninna ninna my little boy-o", etc.

Ninna-nanna, çunin-o³. Preza, Tirana, 1974. Singer: Zoje Brahi. Bob. 1071/17

\footnotetext{
1 Written in notes made by $\mathrm{H}$. Filja

2 Transcripted by Cassette 1132/7

${ }^{3}$ H. Filja: "Folk Songs of the central Albania", The Science Academy of The Socialist Republic of the People of Albania, The Institute of the Folk Culture, "Mihal Duri" Press, Tirana 1991, f 33. 


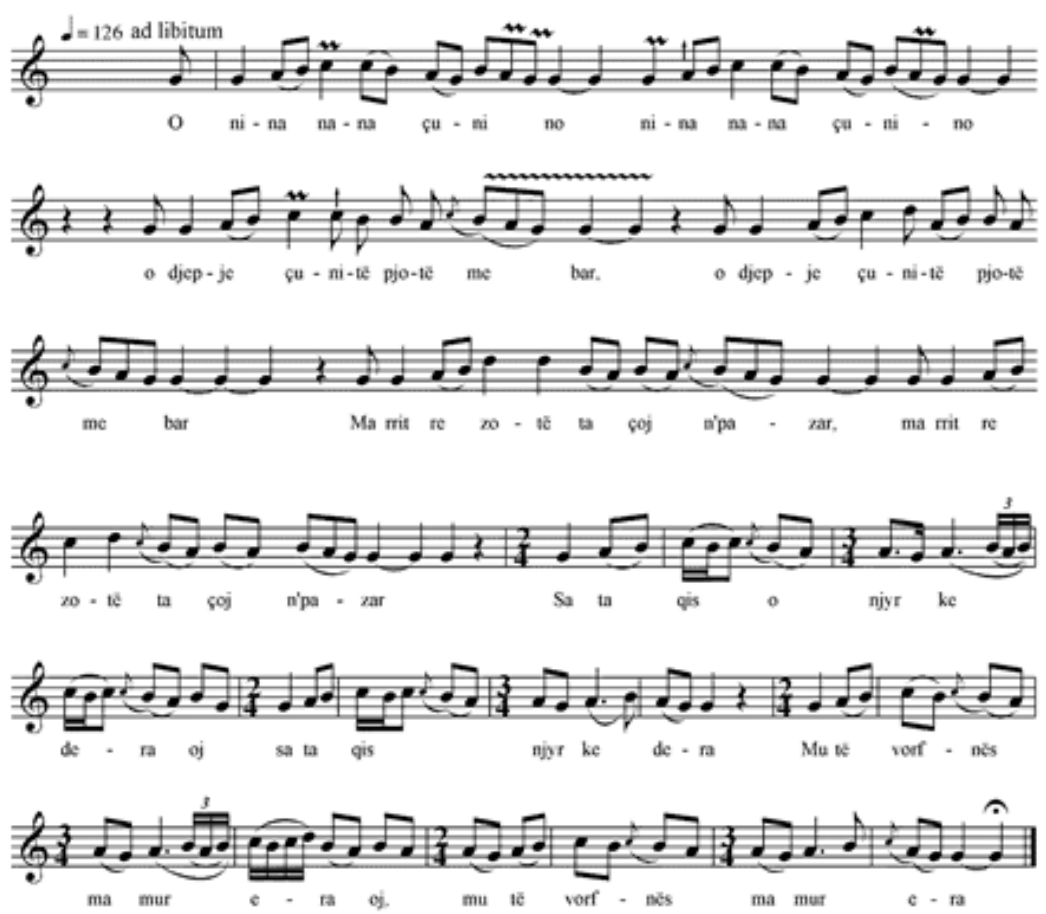

1

Nina-nana, çunin-o, djepje çunit pjot me bar, ma rrit, zot, ta çoj n'pazar.

Përkun nat' e përkun ditë, The south wind roaring loud sa ta qes u ner ke dera, mu të vorfnës ma mur era.
Ninna-Nanna little boy-o

My son's cradle full of grass

Raise him up, God to send him to the store

Cradle in the day, and cradle in the night Era e jugut ulerin

When I take him to the door

Poor me, the wind took him.

The intervals used in this song are: prime, minor second, major second and minor third, major third and the pure quadruple. There is an extent from the note Sol at the second line up to note Re at the fourth line comprising a range of fifth interval. The melodic development is melismatic and we see the use of mordent and the vibration of the voice, while the syllables correspond one per one or one per two notes. Mostly we notice the gradual motion, and only a few leaps.

The Mode used is Lydian or Ionian. We see the Lydian triad sound which expands into a fifth.

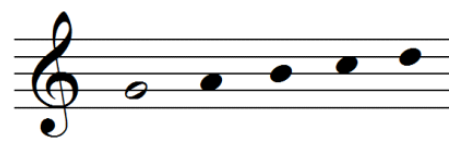

The cadence is going gradually from up to down, as in the majority of the cases. The song starts ad libitum and continues in this form until the middle of it, then we see the combination of the meters $2 / 4$ and $3 / 4$ which are the most common in the lullaby songs. The lines of this lullaby are repeated twice as in the case above. Human beings have always prayed God in

\footnotetext{
${ }^{1}$ Music collected by A. Mustaqi, written in notes by F. Daja.
} 
order to receive the best from life, this is true in our modern times as well, and we find it here at the line where it says: "God make him (the baby) grow up (Ma rrit re Zot)".

In this song there were missing notes and some of the vowels didn't correspond with the published lyrics so we had to rewrite the lyrics from the beginning. Also in the original cassette recording there were two lines missing.

Nina-nana, çunin-o, djepje çunit pjot me bar, ma rrit, zot, ta çoj n'pazar. sa ta qes u ner ke dera, mu të vorfnës ma mur era.

\author{
Ninna-Nanna little boy-0 ${ }^{1}$ \\ My son's cradle full of grass \\ Raise him up, God to send him to the store \\ When I take him to the door \\ Poor me, the wind took him.
}

Another thing that caught our attention is that the lines used here are the same with the lines of a satiric song we sing in a wedding during the women dancing day (traditional Albanian wedding) "My dress with many strings". The reason for this is that usually the women repertoire is made mostly of wedding songs, and there is not much interest in other musical genders, except for 'lullabies' and "grieving songs". And some times, trying to improvise the words, all these verses naturally come to their minds since they have rooted deep in their memory. The melody also has resemblances of this same song. Here are some of the verses of this song:

\section{Funi lis me tela shum}

Funi lis me tela shum

Burri vogël mjera un

Ta fus n'djepe ta përkun

Përkun nat e përkun dit

Jalla zot ma rrit ka i çikë

Sa ta rris ta qis ke dera

Mu të shkretën ç'ma mur era

Erdhi iriqi dhe ma shpoi

Erdhi maca ma gërici

\section{My dress with many strings}

my dress with many strings

My young man, poor me

To the cradle I will put him and rock it

Rock the cradle night and day

Raise him up, God, a little bit

When I take him to the door

Poor me, the wind took him.

The hedgehog came and prickled him

The cat came and scratched him

As we see, the last four lines of the lullaby are the same with the four lines in the middle of the wedding song: "My dress with many strings" or to be more precise the verses four, five, six and seven. In this song we see the use of humor in the lines: "To the cradle I will put him and rock it", "Rock the cradle night and day" and "Raise him up God" these lines give the atmosphere of the lullabies.

Mother rocks the little boy². Shëmri, Tirana, 1974. Singer: Zeqine Roçi (woman). Bob. 1098/10

1 Transcripted from cassette 1071/17

2 H. Filja: "Folk Songs of the central Albania", The Science Academy of The Socialist Republic of the of the Folk Culture, "Mihal Duri" Press, Tirana 1991, f 35. 


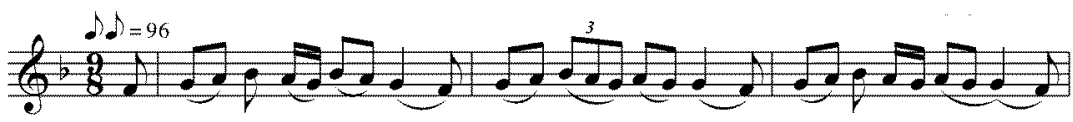

e për - kun në no - na djal ıё vo - gë1 për - ku-në no - na

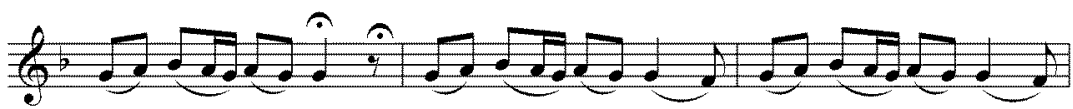

djal në vo - gël

për - kun

no - to

për - kun di - to

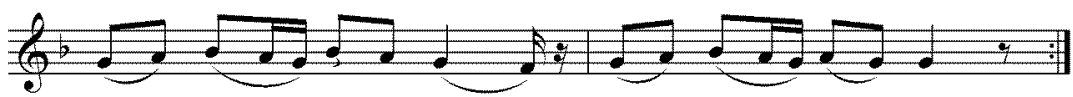

për - kun

no

te

për - kun

di - te

Përkun nana djaln e vogël, përkun nat' e përkun ditë, jalla, zot, ma rrit ka 'i çike. Përkun djalin, ta qis ke dera, djaln e nanës ç'e merr era.

Flej me nanën, more bir, se ty gjumi të ban mirë.
Mother rocks the little boy Rock the cradle night and day

Raise him up, God a little bit Rock my son, take him at the door

The strong wind took my son sleep with your mother my little son Because sleep is good for you. ${ }^{1}$

The intervals used in this song are: prime, minor second, major second and minor third. The extent of this song comprises the range of a pure quarter from note $\mathrm{Fa}$ in the first intervening space to the same note at the third line.

The melody of this song leaps three times in minor third from down - up, but the other part of the song evolves over gradual up and down motions. Melodic line of this song is similar to "O ninna nanna my little son o" song.

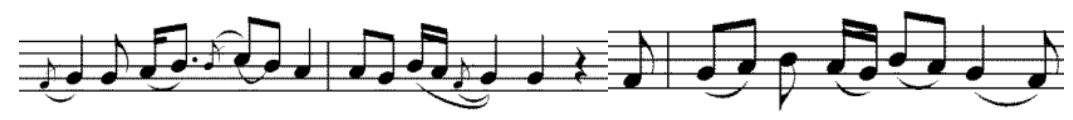

Both these melodies go up and descend gradually, and then leap in minor third descending again gradually.

Mode used:

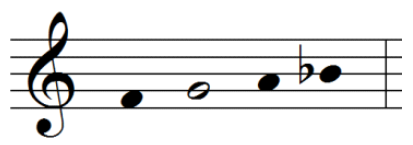

The cadence is made gradually from up-down, La-Sol-Sol, the meter 9/8 rich in images uses fourth-notes, eighth-notes, sixteenth-notes. Furthermore, in one case we see the use of triola which we have not seen before.

Even in this song the three lines in the middle have the same character as in the song: "My dress with many strings" above. The lines are repeated twice, and we notice that the exclamation "o" is replaced by "jalla" which is another exclamation that expresses a wish or begging from God. In this lullaby, as in all the other ones, we find words that describe how important sleep is for children. We find this idea in the lines: "Sleep with your mother my little son; because sleep is good for you."

\footnotetext{
${ }^{1}$ Music collected by H. Filja, written in notes by H. Filja.
} 
Kunu kunu tin mre bir ${ }^{1}$, Vërri, Tirana, 1969, Singer: Aldije Reçeku (woman), Bob. 682/10

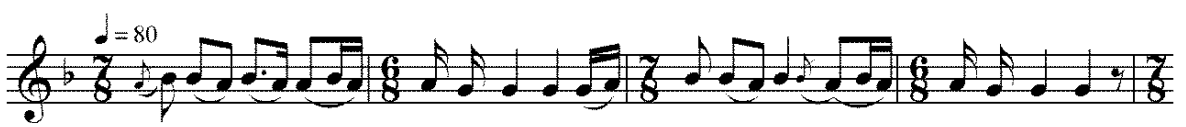
$\mathrm{Ku}-\mathrm{nu} \mathrm{ku}-\mathrm{nu}$
ti në mre bi-rë
$\mathrm{ku}-\mathrm{nu} \quad \mathrm{ku}-\mathrm{nu}$
ti në mre bir

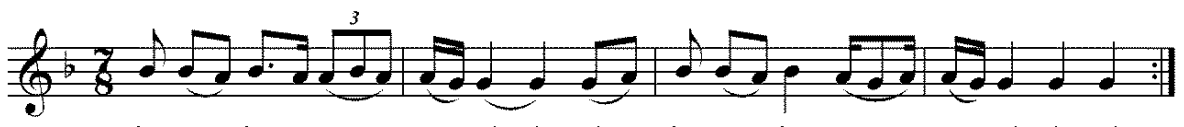

$\mathrm{ku}-\mathrm{nu} \quad \mathrm{ku}-\mathrm{nu}$

të raj gju-mi

$\mathrm{ku}-\mathrm{nu}-\mathrm{ku}-\mathrm{nu}$

të 2aj gaju-mi

Kunu, kunu tin, mre bir, kunu, kunu, të zaj' gjumi, gusha jote a si pëllumi

Rock and rock (the cradle), you my son

Rock and rock (the cradle), fell asleep

Your skin as white as the dove's ${ }^{2}$

The intervals used in this song are: prima, minor second, major second and minor third. The extent of this song is from note Sol in the second line to the note Si in the third line comprising the range of minor third interval.

The melody in this song moves gradually from up-down except for the case when the first ends in Sol and the second line will begin again with note $\mathrm{Si}$, but in both lines we have a leap in minor third. Also something to notice is that there are many repetitions of the same note.

The mode used is:

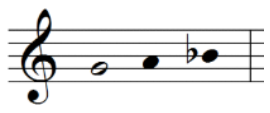

The cadence here is very special because we find the repetition of the same note four times, and that's the note Sol. In the first line we see the combination of the musical meters $7 / 8$ and $6 / 8$, while the second line starts and ends with the meter 7/8. Tempo is fourth equals eighteen.

This song is closer to the northern dialect and we find the words "kunu-kunu" which means "rock and rock (the cradle)", etc. For the first time we find the figure of speech simile, the words compare the child with a dove "just like a dove's". This simile shows the beauty of a healthy face, the concept of being healthy has always been accompanied by the concept of being beautiful or handsome. And in this song it is repeated twice.

Ni-ni-no urulla ${ }^{3}$, Vaqarr 07.04.2015, Singer: Mejte Nurja (woman), CD. Vaqarr. Song 01

\footnotetext{
${ }^{1} \mathrm{H}$. Filja: "Folk Songs of the central Albania", The Science Academy of The Socialist Republic of the Institute of the Folk Culture, "Mihal Duri" Press, Tirana 1991, f 37.

2 Music collected by F. Daja, written in notes by F. Daja

${ }^{3}$ Individual registration. CD Vaqarr; Song 01. 


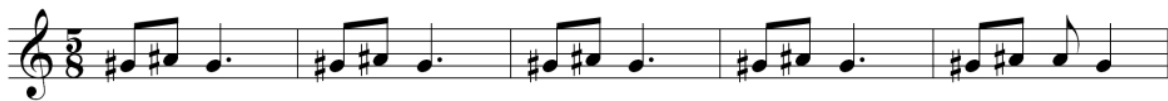
$\mathrm{Ni}-\mathrm{ni}-\mathrm{no}$
u - Ilu - lla
ni - ni - no
u - Ilu - lla
flej - te dja - li

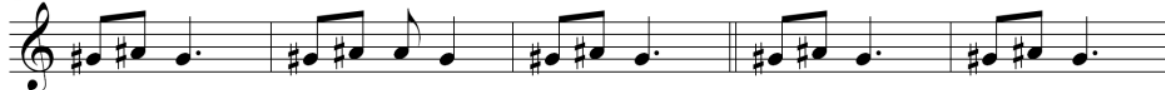
no - nës - o
flej - te dja - li
no - nës - o
ni - ni - no
u - Ilu - Ila

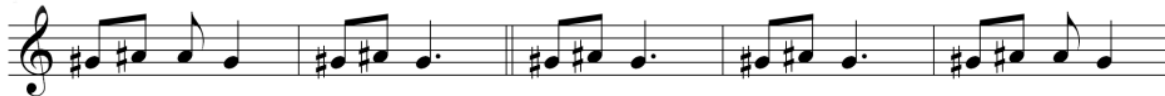
zej - te gju - mi
dja $-\operatorname{lin}-o$
ni - ni - no
ni - ni - no
fle - ti dja - li

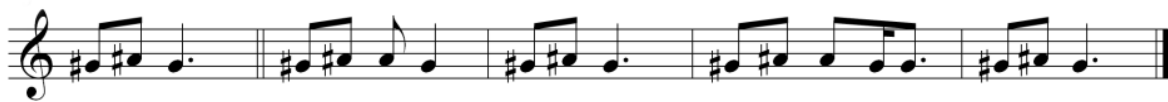

no-nës-o flej-ti dja-li no-nës-o se të rri-tesh $i \quad$ bu-kur-o

Ninin-0, ullulla

Ninin-o, ullulla

Flejte djali nonës-o

Flejte djali nonës-o

Ninin-0, ullulla

Zejte gjumi djalin-o

Ninin-0, ninin-0

Fle ti djali nonës-oSleep little

Flej ti djali nonës-0

Se të rritesh i bukur-o
Ninin-o, ullulla ${ }^{1}$

Ninin-o, ullulla

Did you sleep mother's little boy-o

Did you sleep mother's little boy-o

Ninin-o, ullulla

Go to sleep my son-o

Ninin-0, ninin-o

mother's boy-0

Sleep little mother's boy-o

To grow up and be handsome-o

Unlike the songs we have seen so far, in this song we find only one interval, the interval of the major second and the extension is in the major second from the note sol\# in the second line up to the note la\# in the second intervening space. The melody of this song is very simple because is built only on two notes, it has a syllabic construction. The whole song is built on two musical measures combined with each-other.

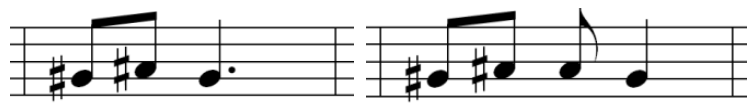

It is a musical composition with two bichordal pitches:

Musical compositions with two pitches start the musical combinations. In the folk music we will see different variations of these two pitches which are chosen to give a specific emotion. ${ }^{2}$

The Mode:

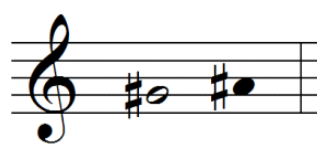

1 Urulla.

2 V.S. Tole "Musical Folklore, Iso Polyphony and Monody', Uegen, Tirana 2007, f 421. 
The cadence comes gradually from down-up, the song is built on the meter $5 / 8$, the value of the notes used more often here are the dotted eighth and the fourth.

In this song, as in most of them, we find the exclamatory at the end of the line, there are no figures of the speech, and the lines used have a specific order. In the seventh line "ninin-o, ninin-o" we have the repetition of the same word twice to make rhythm, which doesn't have a real meaning, the same as 'ninna-nanna'.

The lyrics, as the melody, are very simple; it is a call to the child to fell asleep. As in all the other cases, sleep is the most important of all and besides health it also makes you more beautiful, as we read in the last two lines. "Sleep little mother's boy-o, grow up and be handsome-o".

\section{Conclusions}

Most of the lullabies referred in this study are taken from the study published by the researcher Hysen Filja and we found there lullabies in different areas of our country as for example: Preza, Ndroq, Peza, Zall-Herr, Shëmri and Vërri. But still, his conclusion is that:

\section{These songs are shriveling ${ }^{1}$}

compared to the previous years. We must emphasize though that in our days these songs are almost completely shriveled because we only found them in two areas: Vaqarr and Kërraba. One out of eight songs used in this study has an individual recording: "Ninin-o urulla".

In our days the lullabies or cradle songs, are being forgotten because they are no longer used. The social and cultural development and also the development of the new technology made parents find alternative methods of putting a child to bed, such as toys, recorded music, and many more variations, and not by singing a lullaby, which were mostly sung by the grandmother.

There are two main reasons for this: first, nowadays the couples choose to live apart from their parents, and as a result the children are raised without the presence and influence of the grandparents; and second, for the parents themselves it is almost impossible to do this part as a result of a long and tiresome day at work.

Still, though these cradle songs are no longer used, they live in the memories of their bearers. Although we only found lullabies in the areas of Vaqarr and Kërrabë, we think that there are other areas that use cradle songs to put the babies asleep, but people refuse to express because they don't like to be recorded. We don't know for how much longer these cradle songs will be sung, especially when the bearers will no longer be among us because of the cycle of life.

In these songs, the most used intervals are from perfect unison (prima) to the augmented quadruple, but mostly dominate the intervals up to diminished third. There are other cases though, as in the "ninin-o ullulla" where we find only the interval of the major second. In only one song out of 8 that we studied, we find the augmented second "Nina-nana my boy-o" and it is in the same song that we find the augmented third and the augmented fourth. Mainly the extent of these songs is a quadruple, a fifth or sixth, but there are also cases when it goes up to the third or the second.

The melodies of these songs are some times syllabic and some other times melismatic, but mostly dominate the gradual movements more than those with leaps. There are two reasons for this, first these are vocal compositions and for the human voice it is more easy to perform songs without many leaps, and second is the character of the songs itself because these songs need to be quite in order to put the baby asleep. Usually these melodies, except for the songs "Ninna-nanna my son-o", "Ninna-nanna my boy-o" and "Ni-ni-no urulla", at the other hand have a minor character.

In all this group of songs the cadence is gradually going from up-down, except for the first song "ninna-nanna" which has a leap but still the direction is from up-down. The general mode we think is the Aeolian because it is used more often, but

\footnotetext{
${ }^{1} \mathrm{H}$. Filja: "Folk Songs of the central Albania", The Science Academy of The Socialist Republic of the of the Folk Culture, "Mihal Duri" Press, Tirana 1991, $\mathrm{f} 6$. 
sometimes we find the Phrygian. In our case, in one of the songs we find the Lydian mode but we also have other cases when we find the augmented second. Although it is said that in the cradle songs dominates the meter $2 / 4,3 / 4$ and $3 / 8$, we see that in these songs we are studying it is used also the meter $5 / 8,7 / 8$ and $9 / 8$ (believing that the transcriptions are correct).

The language used in these songs is really simple; we don't see many figures of speech. In these cradle songs (lullabies) we see the mother's desire to have a healthy child by comparing the baby with the dove, with the brave men and heroes. Besides the "nina-nana" lines, which are present in every lullaby, we have also the repetition of the same line in different lullabies. We also have the case when some lines of two of the lullabies studied above "O ninna-nanna my boy-o" and "Ninna-nanna my son-o" are used in a satiric song "My dress with many strings" which is sung in a wedding during the women dancing day.

As we mentioned above in our study, this happens because in the women's repertoire there are mainly wedding songs, and most of them with improvised lines. At the beginning of this study we explained that grandmothers and mothers when putting a baby to sleep sing lullabies to them and while doing so, improvise the word and lines. In the first three songs the lines are sung without repetition, while in the last five songs the lines are repeated twice each.

Some of these songs are late compositions. This can be understood from the child's mother's words. She sings to his school education, occupation, etc. Our former leader of the country Enver Hoxha is mentioned as well. Something else to note is that these songs mentioned in the study, in all cases are sung to the boys and not to the girls. This shows the desire of the Albanians to have boys instead of girls.

Regarding the form of these songs, we cannot specify a particular construction. We find sentences and musical periods built by one or two measures, in some cases we see the same musical motif repeated and in some other cases we have questions and answers. In other songs we have a melody that evolves with time or is repeated continuously. The researcher Ferial Daja says:

The simplicity of the musical language of lullabies stands in the fact that their melody takes the features of a musical sentence which repeats itself in a similar way in every new poetry line, but also it can take the features of a musical period, where sometimes the second sentence despite its poetic line, serves as the chorus. ${ }^{1}$

Conducted analysis were referring to these publications but we need to keep in mind that these publications may have transcription mistakes in scores or in lyrics, or at least only in lyrics.

This probably happens because the lyrics are collected separately from the melody and in most of the cases the lyrics don't fit with the melody in the cassette recording. The cassette may have line replacement, and reduction or extra lines of lyrics. But we cannot say anything more for the score transcription without prior verification.

In this paper, this was not possible, for two reasons, first it was not the purpose of the study and second it requires serious work and other working conditions too, because it is not easy to make a transcription just by hearing the songs.

The Map of the Area Where this Study Was Done 1 F. Daja: "Folk Cradle Songs", The Science Academy of The Socialist Republic of the People of Albania, The Institute of the Folk
Culture, Tirana 1982, f 5. 


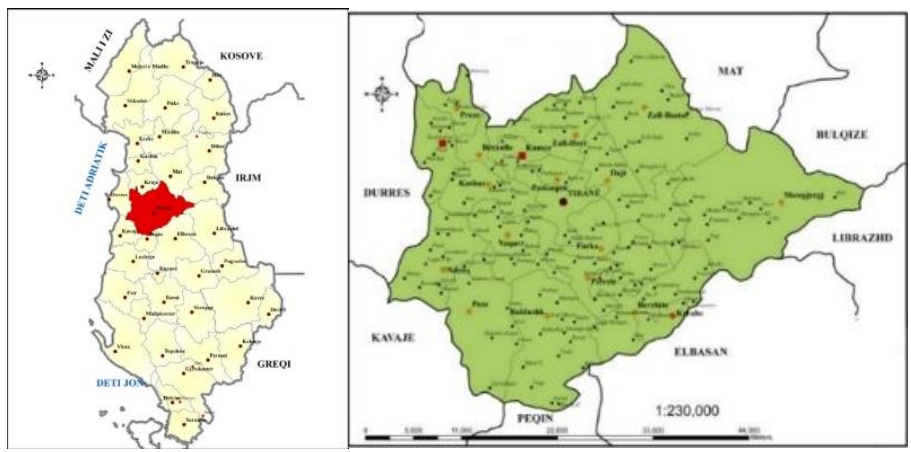

\section{Literature}

[1] Barnet S., Ballanca P., Stubbs M., "Academic writing", "Dita", Tirana 2000

[2] DAJA Ferial, "Folk Cradle Songs", The Science Academy of The Socialist Republic of the People of Albania, The Institute of the Folk Culture, Tirana 1982

[3] DIBRA Miaser, "Metaphors in Albanian folk songs", Academy of Science of Albania, Institute of Folk Culture, Folklore Departament, "Mother Tereza Printing House", Tirana, 2007.

[4] ECO Umberto, "How to write a diploma thesis", "Dituria", Tirana 2007

[5] FILJA Hysen, "Folk Songs of the central Albania", The Science Academy of The Socialist Republic of the People of Albania, The Institute of the Folk Culture, "Mihal Duri" Press, Tirana 1991

[6] GJINARI Jorgji, SHKURTAJ Gjovalin, "Dialectology”, SHBLU, Tirana, 2009.

[7] PAPLEKA Anton, selected "Lyric folk music" (lullabies), "Redona" Pub., Tirana, 2009

[8] SOKOLI Ramadan, "Folklore tracking", "Naim Frashëri", Tirana, 1981.

[9] SHUPO Sokol, "Albanian musical folklore", Vol.I, "ASMUS", Tirana, 2002.

[10] TOLE Vasil.S, "Albanian musical folklore", Iso polyphony and Monody, "Uegen", Tirana, 2007.

[11] ZHEJI Gjergj, "Albanian folklore", Argeta LMG, Tirana, 1998. 